\title{
The changing therapeutic landscape of spinal muscular atrophy
}

\section{Joanne E Davidson, Michelle A Farrar}

This article is the second in a series of articles on important topics in neurology.

\section{Background}

The clinical approach to spinal muscular atrophy (SMA) has changed, and the condition is now a treatable neurodegenerative disease, with treated infants and children experiencing gains in motor function and significant increases in survival. Consequently, it is important for primary care physicians to be aware of their role in both detection and community support of people with SMA and their families.

\section{Objective}

The aim of this article is to discuss the pertinent features of SMA relevant to the primary physician including presenting features, symptoms and signs, prognosis, treatment options and genetic carrier screening for the condition.

\section{Discussion}

SMA is a neuromuscular disorder characterised by progressive proximal muscle weakness. If SMA is suspected, patients should be referred immediately, particularly hypotonic infants and children not obtaining, or falling behind, the motor milestones of their peers. Early recognition and prompt intervention are associated with greater clinical efficacy of genetic disease-modifying therapies. National guidelines recommend carrier screening is offered to all who are considering pregnancy or are in early pregnancy.
THE CLINICAL COURSE OF SPINAL MUSCULAR ATROPHY (SMA) is changing in the era of disease-modifying therapies. What was once a fatal disease at the severe end of the spectrum is becoming a treatable condition with improved functional status and outcomes. Early recognition and prompt intervention are now known to improve clinical outcomes, including survival and acquisition of motor milestones. This places the primary care provider into a pivotal role for early suspicion, recognition and referral for SMA, considering that 'time is motor neuron'. Ongoing care and follow-up will also be increasingly relevant as SMA becomes a chronic care condition requiring routine and disease-specific healthcare.

The aim of this article is to provide an overview of SMA for a primary healthcare setting in the context of a changing clinical course of disease in order to support early suspicion and referral for SMA, thus allowing affected children to access time-critical treatment. In addition, it summarises the novel therapies and important long-term management features pertinent to the general practitioner (GP) caring for these children and families.

\section{What is spinal muscular atrophy?}

SMA is an inherited autosomal recessive neuromuscular disorder characterised by progressive muscle weakness and atrophy in individuals who are cognitively normal. In the general population there is a carrier frequency of approximately one in 40 people, resulting in the condition affecting roughly one in 10,000 live births. ${ }^{1}$

Although a rare disease, untreated SMA is the leading genetic cause of death in children under two years of age. ${ }^{2}$

SMA is caused by a deficiency in the survival motor neuron (SMN) protein due to homozygous mutations in the survival motor neuron 1 (SMN1) gene. An almost identical nearby SMN2 gene can produce a small amount of functional SMN protein. SMN2 copy numbers vary between individuals, and the severity of SMA is largely, although not solely, inversely related to the number of copies of SMN2.,4

\section{How do children with spinal muscular atrophy present?}

People with SMA are on a continuum of severity, from severe hypotonia and weakness to mild proximal muscle weakness and walking unassisted. Historically, SMA has been classified into four major phenotypes (three affecting children) that are separated by the age at symptom onset and maximal motor milestone achieved (Table 1 ).

\section{Symptoms and signs to look for and approach to examination}

The classical clinical triad of SMA is muscle atrophy, fasciculations and areflexia in a cognitively normal child. However, diagnosis can be delayed because subtle early signs may be difficult to detect. For example, as the individual with SMA transitions from presymptomatic to symptomatic, preserved or brisk tendon reflexes may be evident on examination and fasciculations may not yet be present. ${ }^{5,6}$

Affected children experience a progressive, predominantly proximal 
muscle weakness, the presenting symptoms of which will be determined by severity of the disease and age of the child. In infants, severe weakness often results in an inability to obtain basic motor milestones, such as head control or rolling, and may result in swallowing difficulties causing growth failure. ${ }^{3,7}$ Feeding difficulties typically present after the first few weeks of life, and loss of rolling or head control milestones have been reported by parents of children in this age group. ${ }^{5}$ Muscles of the pelvic girdle are commonly affected early, and as a result of the combination of muscle weakness and hypotonia, hips will often be externally rotated with flexed knees, giving a 'frog leg' position. Minimal antigravity movement at the shoulder and significant head lag can be observed. ${ }^{3}$ There is usually relative sparing of the diaphragmatic muscles and, as a result, breathing can appear paradoxical, with intercostal recession and abdominal distension with inspiration. ${ }^{3}$

In older infants aged $>6$ months and children, the signs of weakness can be more subtle. Affected children will typically have an initially normal motor trajectory, including sitting independently. However, they then show difficulties relative to their peers, such as inability or delay in walking; trouble with activities that require proximal muscle groups such as rising from the
Delayed motor milestones, particularly in the first year of life

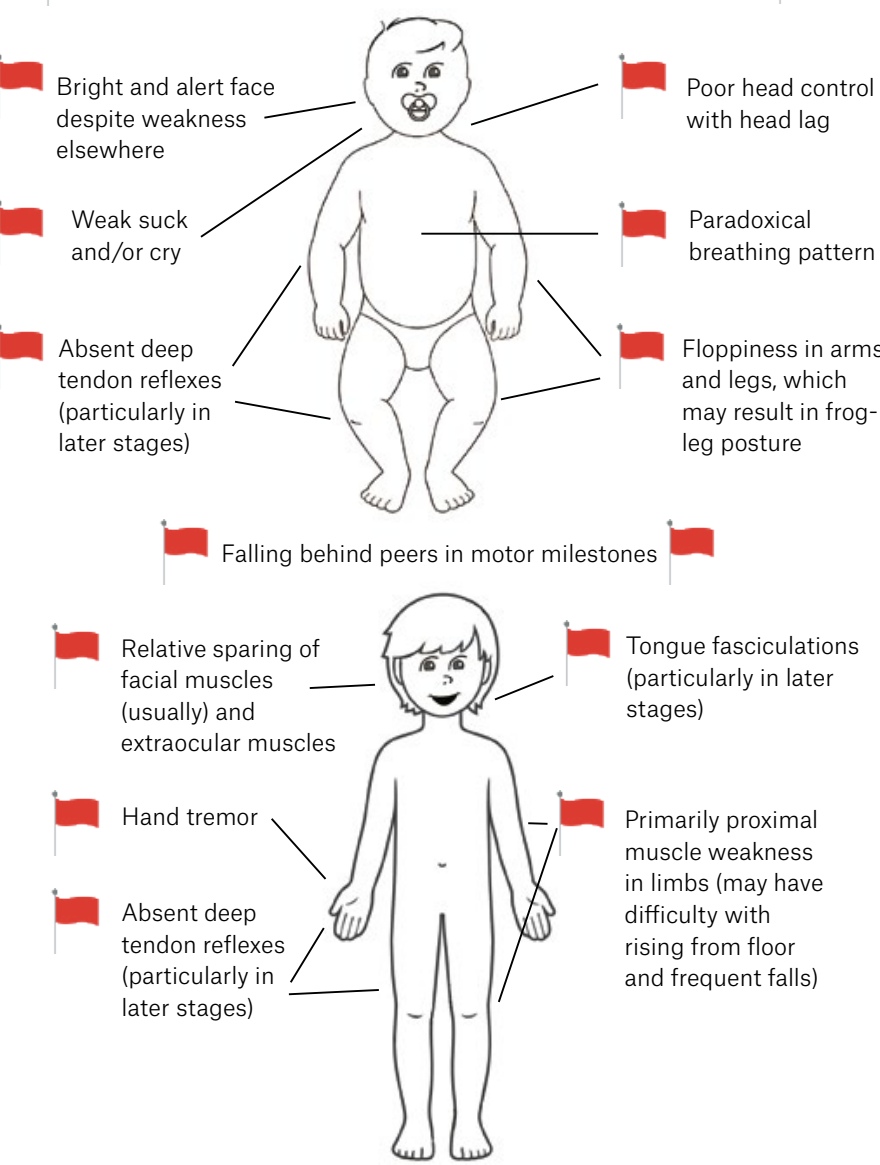

Figure 1. The typical clinical features of an infant and child with spinal muscular atrophy

Table 1. A summary of spinal muscular atrophy (SMA) subtype classification and presentation ${ }^{2,4,7,23-25}$

\begin{tabular}{|c|c|c|c|c|c|c|}
\hline $\begin{array}{l}\text { SMA } \\
\text { type }\end{array}$ & Incidence & Age of onset & $\begin{array}{l}\text { Best motor } \\
\text { milestone }\end{array}$ & $\begin{array}{l}\text { Untreated } \\
\text { life span }\end{array}$ & $\begin{array}{l}\text { Typical SMN2 } \\
\text { copy number }\end{array}$ & Presenting features \\
\hline 1 & $\sim 60 \%$ of cases & $0-6$ months & Never sits & $\begin{array}{l}<2 \text { years } \\
\text { (without respiratory } \\
\text { support) }\end{array}$ & $\begin{array}{l}80 \% \text { of patients } \\
\text { have } 1-2 \text { copies }\end{array}$ & $\begin{array}{l}\text { Poor head control, hypotonia, absent } \\
\text { tendon reflexes, 'frog leg' posture, } \\
\text { tongue fasciculations, poor swallow, } \\
\text { paradoxical breathing }\end{array}$ \\
\hline 2 & $\sim 27 \%$ of cases & 6-18 months & $\begin{array}{l}\text { Sits } \\
\text { independently }\end{array}$ & $\begin{array}{l}\text { Most }(\sim 70 \%) \text { alive } \\
\text { at } 25 \text { years }\end{array}$ & $\begin{array}{l}>80 \% \text { of patients } \\
\text { have three copies }\end{array}$ & $\begin{array}{l}\text { Absent tendon reflexes, scoliosis, } \\
\text { low muscle tone, proximal weakness, } \\
\text { motor delay with difficulty standing/ } \\
\text { walking, hand tremor }\end{array}$ \\
\hline $3 a$ & \multirow[t]{2}{*}{$\sim 12 \%$ of cases } & $>18$ months & \multirow[t]{2}{*}{$\begin{array}{l}\text { Stands } \\
\text { and walks }\end{array}$} & \multirow[t]{2}{*}{ Almost normal } & \multirow[t]{2}{*}{$\begin{array}{l}96 \% \text { of patients } \\
\text { have } 3-4 \text { copies }\end{array}$} & \multirow{2}{*}{$\begin{array}{l}\text { Proximal weakness greater in legs than } \\
\text { arms, waddling gait, trouble with stairs } \\
\text { and rising from floor, hand tremor }\end{array}$} \\
\hline $3 b$ & & $>3$ years & & & & \\
\hline 4 & $\sim 1 \%$ of cases & $>21$ years & Normal & Normal & $\begin{array}{l}75 \% \text { have four } \\
\text { or more copies }\end{array}$ & Adult-onset mild proximal weakness \\
\hline
\end{tabular}


floor, climbing and descending stairs; and frequent falling. ${ }^{5,8}$ Examination may show objective weakness in these muscle groups and possibly the presence of wasting, fasciculations and areflexia. Figure 1 outlines these features.

Many of these symptoms and signs have overlap with other neuromuscular conditions, such as congenital myopathies, limb-girdle muscular dystrophies and dermatomyositis. Suspicion for SMA is important, as it can be delineated on testing, allowing for implementation of disease-specific treatment.

\section{How to refer a child with worrying signs or symptoms} Possible cases of SMA type 1 are best referred promptly and directly to the neuromuscular clinic in each state via the local tertiary paediatric hospital. If the practitioner is working in a regional centre without a tertiary paediatric centre in reasonable proximity, it may be best to refer initially to the local paediatric service, noting concern regarding possible SMA to ensure the referral is triaged appropriately. A single blood test can confirm if a child has the mutations in the SMN1 gene that causes SMA. Practitioners working in remote regions who have clinical concern regarding SMA can arrange this test to be collected locally and sent to a specialised laboratory, following discussion with a geneticist or neuromuscular specialist.

Diagnostic delays are known to occur in SMA. A systematic review revealed the time between symptom onset and diagnosis was 3.6, 14.3 and 43.6 months for SMA types 1, 2 and 3, respectively. ${ }^{9}$ Preclinical and clinical studies have collectively shown the benefits of early initiation of treatment in SMA for the most efficacious and optimal outcomes. ${ }^{10}$
Across several countries internationally and as a pilot program in Western Australia, New South Wales and the Australian Capital Territory, newborn screening for SMA is being introduced to expedite early detection for SMA and allow treatment initiation. ${ }^{11,12}$ It is important to note, however, that a normal previous newborn screening test, while often reassuring, cannot exclude all cases of SMA as the sensitivity is approximately 95\%. Consequently, clinical suspicion for SMA should always result in a timely referral to the local paediatric neuromuscular services.

\section{Prognosis and treatment options} There are now several SMN-dependent disease-modifying therapies for SMA: two SMN2 splice modulators and gene therapy. ${ }^{10,13-16}$ Table 2 summarises the major treatments, their methods

Table 2. A summary of disease-modifying therapies for spinal muscular atrophy ${ }^{10,13-16}$

\begin{tabular}{|c|c|c|c|c|}
\hline Therapy & $\begin{array}{l}\text { TGA indication and PBS } \\
\text { reimbursement in Australia }\end{array}$ & Mechanism of action & Administration & Safety information \\
\hline Nusinersen & $\begin{array}{l}\text { Patients with SMA types } \\
1-3 \text { initiating treatment } \\
\text { before } 18 \text { years of age. } \\
\text { Presymptomatic SMA with } \\
\text { two SMN2 copies. }\end{array}$ & $\begin{array}{l}\text { Antisense oligonucleotide } \\
\text { that targets an intronic } \\
\text { splicing silencer and thus } \\
\text { promotes exon } 7 \text { inclusion } \\
\text { in SMN2 pre-mRNA to } \\
\text { encode full-length SMN } \\
\text { protein. }\end{array}$ & $\begin{array}{l}\text { Intrathecal with four } \\
\text { loading injections } \\
\text { in first two months } \\
\text { then ongoing } \\
\text { maintenance every } \\
\text { four months. }\end{array}$ & $\begin{array}{l}\text { Reported side effects largely relate } \\
\text { to mode of administration and may } \\
\text { include significant treatment anxiety, } \\
\text { localised pain and post-lumbar } \\
\text { puncture headache. }\end{array}$ \\
\hline $\begin{array}{l}\text { Onasemnogene } \\
\text { abeparvovec } \\
\text { (previously known } \\
\text { as AVXS-101) }\end{array}$ & $\begin{array}{l}\text { Presymptomatic and } \\
\text { symptomatic SMA with } \\
1-3 \text { copies of SMN2 aged } \\
\text { less than nine months. } \\
\text { PBAC recommendation } \\
\text { of Section } 100 \text { (Highly } \\
\text { Specialised Drugs Program) } \\
\text { listing at September } 2021 \\
\text { meeting. } \\
\text { An outcomes-based Risk } \\
\text { Sharing Arrangement is } \\
\text { required before possible } \\
\text { PBS reimbursement. }\end{array}$ & $\begin{array}{l}\text { SMN1 gene replacement } \\
\text { therapy, using an adeno- } \\
\text { associated virus capsid to } \\
\text { supply a functional SMN1 } \\
\text { gene to motor neuron cells. }\end{array}$ & $\begin{array}{l}\text { Single dose of } \\
\text { virus vector given } \\
\text { intravenously. }\end{array}$ & $\begin{array}{l}\text { Liver enzymes may become elevated } \\
\text { and cause acute serious liver injury. } \\
\text { Decreased platelet counts } \\
\text { could occur following infusion } \\
\text { and can result in thrombotic } \\
\text { microangiopathy. } \\
\text { Patients will receive an oral } \\
\text { corticosteroid before and after } \\
\text { infusion and will undergo regular } \\
\text { blood tests to monitor liver function. }\end{array}$ \\
\hline $\begin{array}{l}\text { Risdiplam } \\
\text { (originally known } \\
\text { as R0703406) }\end{array}$ & $\begin{array}{l}\text { PBS listed for patients with } \\
\text { SMA types } 1-3 \text { initiating } \\
\text { treatment between the ages } \\
\text { of two months and } 18 \text { years. }\end{array}$ & $\begin{array}{l}\text { Small molecule that } \\
\text { promotes exon } 7 \text { inclusion } \\
\text { in SMN2 pre-mRNA and } \\
\text { full-length SMN protein } \\
\text { production. }\end{array}$ & $\begin{array}{l}\text { Oral medication with } \\
\text { good bioavailability } \\
\text { in the CNS and } \\
\text { peripheral tissues. }\end{array}$ & $\begin{array}{l}\text { No serious adverse events related to } \\
\text { the medication have been reported } \\
\text { in studies to date. }\end{array}$ \\
\hline
\end{tabular}

CNS, central nervous system; PBAC, Pharmaceutical Benefits Advisory Committee; PBS, Pharmaceutical Benefits Scheme; SMA, spinal muscular atrophy; SMN, survival motor neuron; TGA, Therapeutic Goods Administration 
of action, administration details and important side effects or details for GPs to know and commercial status in Australia in October 2021.

Clinical trials and real-world evidence in people with SMA (defined by age, SMA type and baseline motor function) have shown that these therapies produce improvements in survival, motor function and quality of life. The effects of treatment for all people with SMA are yet to be fully determined; however, it is expected that treatments will provide stabilisation and modest improvements in current motor function rather than recovery of already lost motor neurons. ${ }^{10,13,14}$ Initiation of treatment in the presymptomatic phase for infants predicted to develop SMA in infancy or childhood has shown the greatest efficacy, with $88 \%$ achieving independent walking at a mean age of 20.4 months (range
15.5-29.7 months) and none requiring permanent ventilatory support. ${ }^{17}$

Multidisciplinary management approaches for SMA continue to form a pivotal part of treatment. Even with treatment, affected patients are likely to experience complications and ongoing disability from SMA. Management goals are individualised, based on the patient's current motor function. Multidisciplinary care should include specialist neurology, respiratory and orthopaedic care with trained medical professionals, rehabilitation, physiotherapy, nutrition and genetic counselling with active and directed management of comorbidities. ${ }^{18,19}$ Palliative care remains an important cornerstone in some individuals' care, and goals are largely determined by the individual patient and family and may involve a combination of novel therapies, non-invasive nutritional

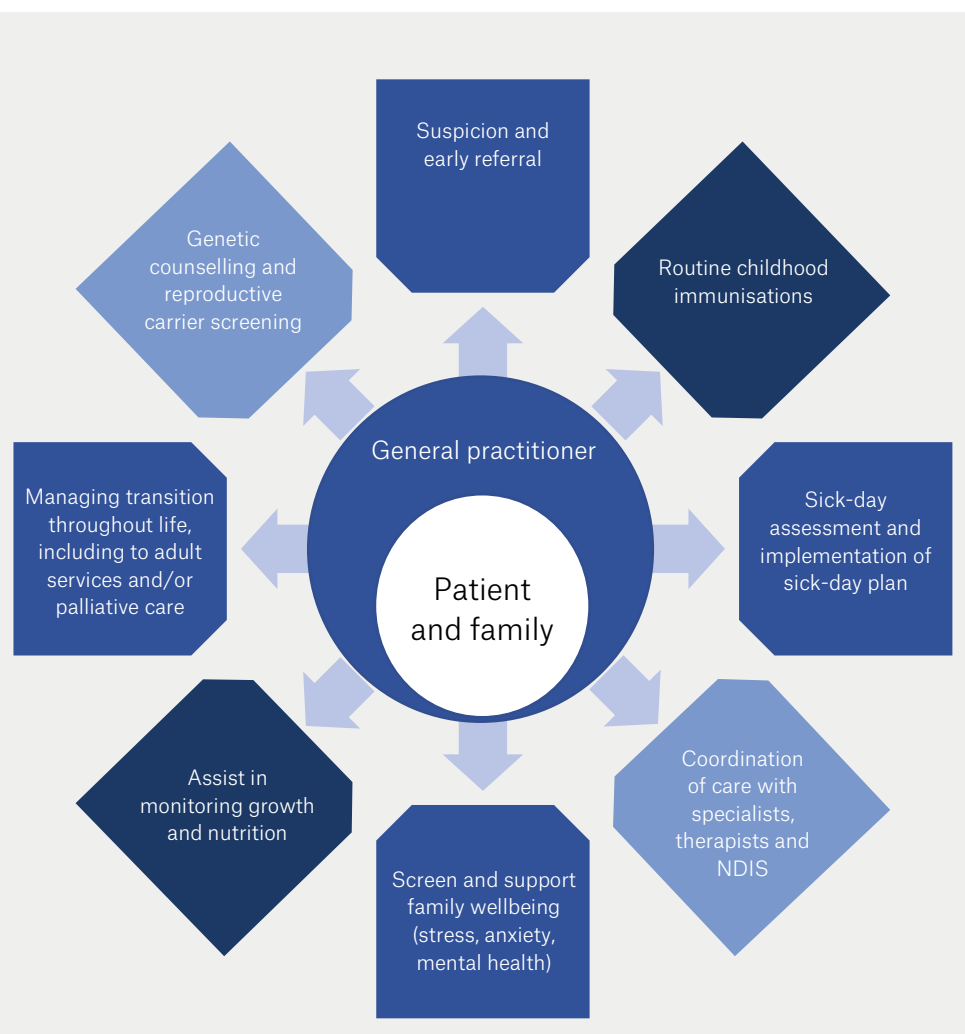

Figure 2. Community management of a child with spinal muscular atrophy overlaps with several important roles that the general practitioner typically provides to families, working in alignment with the multidisciplinary team. ${ }^{17,18}$

NDIS, National Disability Insurance Scheme

and respiratory support. ${ }^{19}$ It is foreseeable that the GP will play an increasingly active part in the community care of children with SMA treated with life-prolonging disease-modifying therapies, including transition to adult care and/or primarily palliative services. As a key support, the GP typically works closely with the paediatrician and neurology services to optimise health through monitoring growth and nutrition, immunisation and implementation of sick-day plans specific to the individual's symptoms and health status (eg early initiation of antibiotics, intensification of chest physiotherapy and assessing the need for hospitalisation in respiratory tract infections). ${ }^{18,19}$ This is summarised in Figure 2.

\section{Can spinal muscular atrophy carrier status be screened for?}

National guidelines now recommend all women or couples planning a family, or who are in the first trimester of pregnancy, be given the option of genetic carrier screening to understand their risk and allow couples to explore their reproductive choices. ${ }^{20,21}$ The ethical considerations arising from developments in SMA testing and treatment warrant ongoing examination.

\section{Conclusion}

SMA is now a treatable neurodegenerative disease, and early detection and treatment are crucial. As a result of the availability of novel, time-critical treatment options, GPs are now playing a key part in the early recognition of this condition. It is important that all GPs consider urgent referral for a child with delayed motor milestones and signs of symmetrical weakness.

\section{Key points}

- SMA is an important cause of childhood morbidity and mortality.

- New disease-modifying therapies, particularly if implemented early, are significantly changing the prognostic trajectory of SMA.

- GPs have a key role in the early detection and referral of these patients, with early suspicion being paramount. 
- Key clinical findings are a progressive primary proximal muscle weakness, which in infants includes failure to obtain basic motor milestones in the first year of life, poor head control and floppy tone and posture in an otherwise bright and alert child.

- Affected children may have difficulty keeping up with peers in motor milestones, fall frequently and have difficulty with stairs.

\section{Resources}

- ClinicalTrials.gov (www.clinicaltrials. gov) - a database of privately and publicly funded clinical studies conducted around the world. This is a useful site to refer families to for up-to-date information regarding novel treatments.

- Australian Neuromuscular Disease Registry (www.australiannmdregistry. org.au/type-of-diseases/sma) - an Australia-wide registry of people diagnosed with a neuromuscular disease. It collects important medical information from adult and child patients across the country to improve the understanding of neuromuscular disease and accelerate the development of new therapies.

\section{Authors}

Joanne E Davidson BMed/MD, General Paediatrics and Paediatric Neurology Advanced Trainee, Sydney Children's Hospital Network, NSW

Michelle A Farrar MBBS (Hons), PhD, FRACP,

Paediatric Neurologist, Sydney Children's Hospital, Randwick, NSW; Associate Professor, School of

Women's and Children's Health, University of NSW, Sydney, NSW

Competing interests: MAF reports personal fees from Biogen, Roche and Novartis outside of the submitted work.

Funding: MAF received grant support from the National Health and Medical Research Council of Australia: Investigator grant (APP1194940).

Provenance and peer review: Not commissioned, externally peer reviewed.

\section{Correspondence to:}

joanne.davidson1@health.nsw.gov.au

\section{Acknowledgements}

This article follows a collaborative project with The Royal Australian College of General Practitioners (RACGP), 'Beware the Rare'. The project includes general practitioners, obstetrics/ gynaecology specialists, geneticists and consumer representatives. The recommendations align with co-developed and RACGP-endorsed resources. ${ }^{22}$
The authors thank the RACGP for review of and feedback on the manuscript.

\section{References}

1. Burns JK, Kothary R, Parks RJ. Opening the window: The case for carrier and perinatal screening for spinal muscular atrophy. Neuromuscul Disord 2016;26(9):551-59. doi: 10.1016/j.nmd.2016.06.459.

2. Carré A, Empey C. Review of spinal muscular atrophy (SMA) for prenatal and pediatric genetic counselors. J Genet Couns 2016;25(1):32-43. doi: 10.1007/s10897-015-9859-z.

3. Farrar MA, Johnston HM, Grattan-Smith $P$, Turner A, Kiernan MC. Spinal muscular atrophy: Molecular mechanisms. Curr Mol Med 2009:9(7):851-62. doi: 10.2174/156652409789105516.

4. Wirth B, Karakaya M, Kye MJ, Mendoza-Ferreira N. Twenty-five years of spinal muscular atrophy research: From phenotype to genotype to therapy, and what comes next. Annu Rev Genomics Hum Genet 2020;21:231-61. doi: 10.1146/annurevgenom-102319-103602.

5. lannaccone ST, Browne RH, Samaha FJ, Buncher CR. Prospective study of spinal muscular atrophy before age 6 years. DCN/ SMA Group. Pediatr Neurol 1993;9(3):187-93. doi: 10.1016/0887-8994(93)90082-n.

6. Oskoui M, Kim DH, Mentis GZ, De Vivo DC. Transient hyperreflexia: An early diagnostic clue in later-onset spinal muscular atrophy. Neurol Clin Pract 2020;10(6):e66-67. doi: 10.1212/ CPJ.0000000000000810.

7. Rudnik-Schöneborn S, Forkert R, Hahnen E, Wirth B, Zerres K. Clinical spectrum and diagnostic criteria of infantile spinal muscular atrophy: Further delineation on the basis of SMN gene deletion findings. Neuropediatrics 1996;27(1):8-15. doi: 10.1055/s-2007-973741.

8. Tonali P, Servidei S, Uncini A, Restuccia D, Galluzzi G. Clinical study of proximal spinal muscular atrophy. Report on 89 cases. Ital J Neuro Sci 1984;5(4):423-32. doi: 10.1007/BF02042627.

9. Lin CW, Kalb SJ, Yeh WS. Delay in diagnosis of spinal muscular atrophy: A systematic literature review. Pediatr Neurol 2015;53(4):293-300. doi: 10.1016/j.pediatrneurol.2015.06.002

10. Ramdas S, Servais L. New treatments in spinal muscular atrophy: An overview of currently available data. Expert Opin Pharmacother 2020;21(3):307-15. doi: 10.1080/14656566.2019.1704732.

11. Kariyawasam DST, Russell JS, Wiley V, Alexander IE, Farrar MA. The implementation of newborn screening for spinal muscular atrophy: The Australian experience. Genet Med 2020;22(3):557-65. doi: 10.1038/s41436-0190673-0.

12. Department of Minister for Health. Media Statements: Assessment of rare genetic disorder for inclusion in WA Newborn Bloodspot Screening Program. West Perth, WA: Government of Western Australia, 2021. Available at www.mediastatements. wa.gov.au/Pages/McGowan/2021/08/ Assessment-of-rare-genetic-disorder-for-inclusionin-WA-Newborn-Bloodspot-Screening-Program. aspx [Accessed 15 October 2021].

13. Kariyawasam D, Carey KA, Jones KJ, Farrar MA New and developing therapies in spinal muscular atrophy. Paediatr Respir Rev 2018;28:3-10. doi: 10.1016/j.prrv.2018.03.003.

14. Farrar MA, Kiernan MC. The genetics of spinal muscular atrophy: Progress and challenges.
Neurotherapeutics 2015;12(2):290-302. doi: 10.1007/s13311-014-0314-x.

15. Australian Government Department of Health. The Pharmaceutical Benefits Scheme: Nusinersen. Canberra, ACT: Commonwealth of Australia. Available at www.pbs.gov.au/medicine/ item/11363C-11378W [Accessed 20 March 2021].

16. Australian Government Department of Health. The Pharmaceutical Benefits Scheme: Onasemnogene Abeparvovec. Canberra, ACT: Commonwealth of Australia. Available at www.pbs.gov.au/ medicinestatus/document/157.html [Accessed 20 March 2021].

17. De Vivo DC, Bertini E, Swoboda KJ, et al. Nusinersen initiated in infants during the presymptomatic stage of spinal muscular atrophy: Interim efficacy and safety results from the Phase 2 NURTURE study. Neuromuscul Disord 2019;29(11):842-56. doi: 10.1016/j. nmd.2019.09.007.

18. Mercuri E, Finkel RS, Muntoni F, et al. Diagnosis and management of spinal muscular atrophy: Part 1: Recommendations for diagnosis, rehabilitation, orthopedic and nutritional care. Neuromuscul Disord 2018;28(2):103-15. doi: 10.1016/j.nmd.2017.11.005.

19. Finkel RS, Mercuri E, Meyer OH, Simonds AK, et al. Diagnosis and management of spinal muscular atrophy: Part 2: Pulmonary and acute care; medications, supplements and immunizations; other organ systems; and ethics. Neuromuscul Disord 2018:28(3):197-207. doi: 10.1016/j.nmd.2017.11.004.

20. The Royal Australian and New Zealand Colleges of Obstetricians and Gynaecologists. College statements and guidelines: Genetic carrier screening. Melbourne, Vic: RANZCOG, 2019.

21. The Royal Australian College of General Practitioners. RACGP guidelines: Reproductive carrier screening. East Melbourne, Vic: RACGP, 2018.

22. The Royal Australian College of General Practitioners. Beware the rare: A guide to the early referral and diagnosis of spinal muscular atrophy (SMA) and other paediatric neuromuscular disorders. East Melbourne, Vic: RACGP, 2020.

23. Markowitz JA, Singh P, Darras BT. Spinal muscular atrophy: A clinical and research update. Pediatr Neurol 2012;46(1):1-12. doi: 10.1016/j. pediatrneurol.2011.09.001.

24. Mercuri E, Bertini E, lannaccone ST. Childhood spinal muscular atrophy: Controversies and challenges. Lancet Neurol 2012;11(5):443-52. doi: 10.1016/S1474-4422(12)70061-3.

25. Verhaart IEC, Robertson A, Wilson IJ, et al. Prevalence, incidence and carrier frequency of $5 q$-linked spinal muscular atrophy - A literature review. Orphanet J Rare Dis 2017:12(1):124. doi: 10.1186/s13023-017-0671-8. 